\title{
The Sponge Gardens of Ningaloo Reef, Western Australia
}

\author{
Andrew Heyward ${ }^{1}$, Jane Fromont ${ }^{2}$, Christine Hanna Lydia Schönberg ${ }^{*}, 1$, Jamie Colquhoun ${ }^{1}$, \\ Ben Radford ${ }^{1}$ and Oliver Gomez ${ }^{2}$
}

\author{
${ }^{1}$ Australian Institute of Marine Science at the University of Western Australia, 35 Stirling Highway, Crawley, WA 6009, \\ Australia \\ ${ }^{2}$ Department of Aquatic Zoology, Western Australian Museum, Locked Bag 49, Welshpool DC, WA 6986, Australia
}

\begin{abstract}
Preliminary results from biodiversity surveys in the deeper waters of Ningaloo Marine Park, Western Australia revealed that while much of the area is composed of sediments and rhodolith fields with low densities of macroepibenthos, locally dense and extensive filter feeding communities exist. They were distinctly dominated by demosponges, both in biomass and diversity. A subsample of dominant taxa determined by fresh weight yielded 155 different demosponge species from over 350 transects between 18-102 m depth. Data from three successive years of sampling indicated that only a few species were ubiquitous, suggesting that as minor species are identified the cumulative species list will significantly exceed the present species record. This implies greatly enhanced biodiversity values associated with Ningaloo Marine Park, complementing records attributed to the shallow coral reef environment. The richness of the observed filter feeding communities adds additional weight to the increasing perception of Australia as a global hotspot for Porifera biodiversity.
\end{abstract}

Keywords: Porifera, Ningaloo Reef, Western Australia, biodiversity hotspot, distribution, towed underwater video, deep water sessile benthic communities.

\section{THE NINGALOO SPONGE GARDENS}

\section{Description of the Habitat and Background to the Survey Work}

Extending nearly $300 \mathrm{~km}$ adjacent to the coastline, Ningaloo Reef in Western Australia is the largest fringing coral reef system in Australia and one of the longest in the world $\left[21.5-24^{\circ} \mathrm{S} ; 1,2\right]$. The reef is readily accessible from shore, with a sheltered 1-4 km wide lagoon extending from the beach to a shallow reef crest, which then slopes quickly to depths of around $30-40 \mathrm{~m}$, often in typical spur and groove formation. A more gradual slope stretches across the continental shelf reaching around $100 \mathrm{~m}$ water depth in the south and over $200 \mathrm{~m}$ in the north where the shelf is narrow [2].

Based on studies on corals, fishes, molluscs and crustaceans, Ningaloo Reef lies within a region identified as a marine biodiversity hotspot and is considered to be one of the 18 richest multi-taxon centres of endemism vulnerable to extinction worldwide [3]. In the same area diverse filterfeeding communities have been identified at depths between 20-200 metres [4], however, little was known of the species that occur there or their ecology. In addition to its biological values, Ningaloo Reef has a considerable socio-economic importance and annually attracts 300,000 tourists, growing by $10 \%$ each year [5]. To protect the socio-economic values and to conserve and manage the natural habitat, almost the entire reef system was declared a Marine Park under

*Address correspondence to this author at the Australian Institute of Marine Science at the University of Western Australia, 35 Stirling Highway, Crawley, WA 6009, Australia; Tel: +61-8-63694042; Fax: +61-8-64884585; E-mail: c.schoenberg@aims.gov.au complimentary State and Commonwealth Acts in 1987 [6], and since $200534 \%$ of its area has been designated as marine protected area (MPA no-take zone) [7].

Previous research at Ningaloo has focused on shallow parts of the coral reef system rather than on the deeper waters seaward of the reef. Scientific diving biases surveys to safe depths of less than $30 \mathrm{~m}$, and the strongest known conservation values for the park at the time of declaration were associated with the nearshore, easily studied coral reef system. Nevertheless, the Park's State boundaries extend three nautical miles seawards of the reef crest, and the majority of the $4,566 \mathrm{~km}^{2}$ of the Marine Park lie beyond the reef crest in depths below $30 \mathrm{~m}$, and sometimes deeper than $200 \mathrm{~m}$ (Fig. 1). The same is true for a large proportion of the MPAs, even though information used to establish these areas was generated in the shallow areas of the park. The paucity of knowledge about seabed biodiversity in the intermediate and deeper waters of the Ningaloo Marine Park has been recognised since the Park's inception in 1987.

Consequently a research program was initiated in 2006 aiming to map the deeper waters of the Park, to generate a geological context, and to establish a baseline biodiversity database for biota occurring in depths between 30 and $125 \mathrm{~m}$ [see 8]. Intensive investigations at Ningaloo Reef followed to assess the distributions of the various biological communities and to determine whether they were adequately represented in the existing MPAs [9]. Surveys revealed that sponges frequently represent the dominant component of the sessile benthic communities. Three years of cumulative fieldwork employed acoustic methods, imaging techniques and traditional sled hauls. Identification of dominant sponges from this sampling period has been completed to operational 


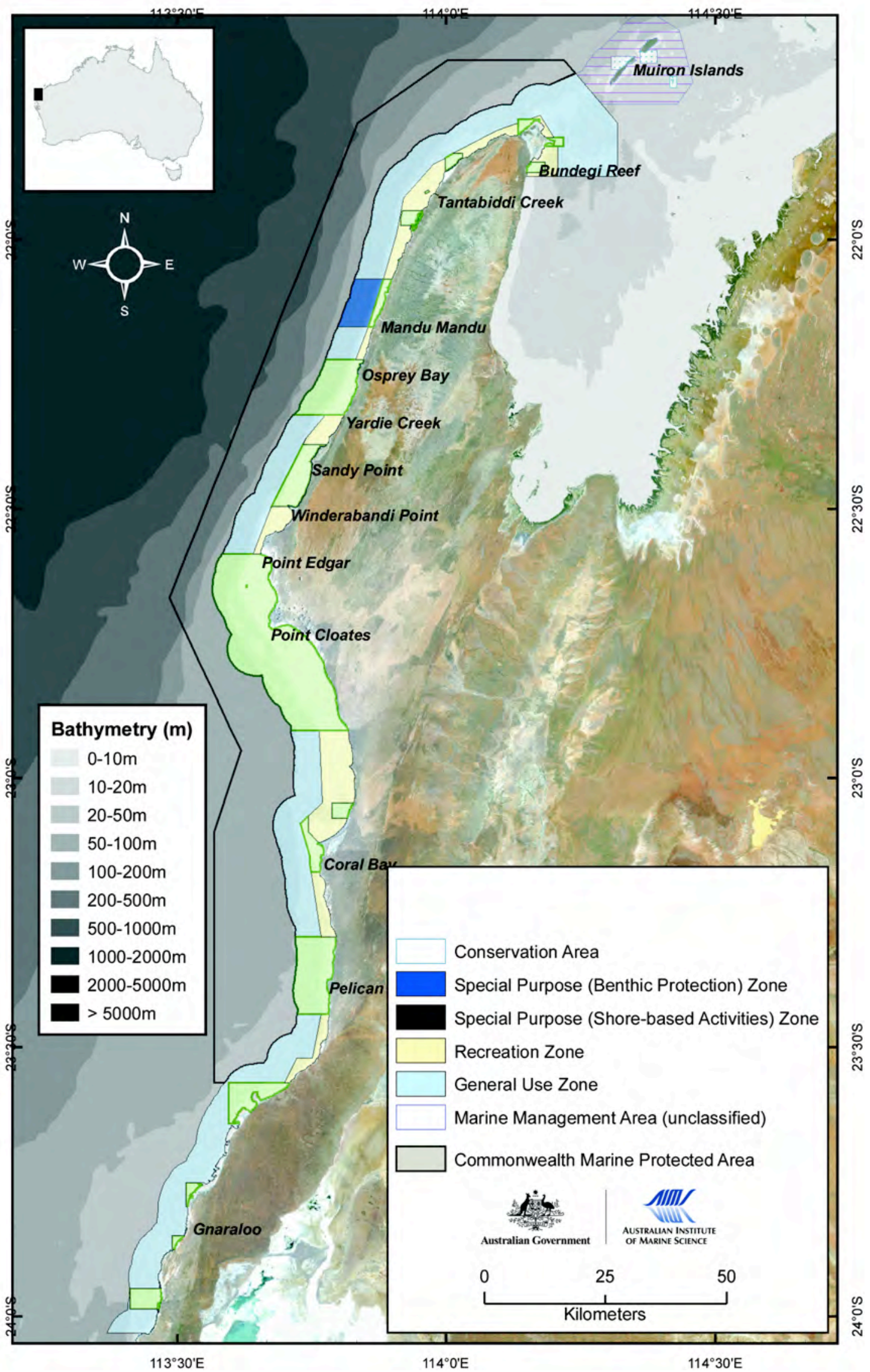

Fig. (1). Map of Ningaloo Marine Park and Muiron Island Marine Management Area: zoning and deepwater bathymetry. Compiled by Felicity McAllister, AIMS. 
taxonomic units (OTUs). This publication focuses on this biological data set and introduces the Ningaloo sponge community to the scientific world.

\section{SURVEY METHODS AND ANALYSES}

Data were collected during various field trips 2006-09 on board the Australian Institute of Marine Science (AIMS) research vessels $R V$ Cape Ferguson and $R V$ Solander along Ningaloo Reef, Western Australia between 21.5 and $24^{\circ} \mathrm{S}$. In 2007, to ensure adequate sampling effort throughout the (Marine Park, sampling was stratified at $5 \mathrm{~km}$ intervals from Point Murat in the north to Red Bluff in the south, Fig. 1). At each station three to four $500 \mathrm{~m}$ transects were sampled from the reef front to the seaward marine park boundary following depth contours parallel to the coast. C-Map ${ }^{\mathrm{TM}}$ vector charts and Maxsea ${ }^{\mathrm{TM}}$ electronic navigation software were used to record the ship's track and water depth. Underwater imagery was collected at an average speed of 1.5 knots along the transects by towing a balanced frame to which the following equipment was attached: a pair of powerful headlights, an underwater colour video camera continuously filming forwards, and an underwater digital still camera with strobes, automatically taking photos every eight seconds while pointing downwards (Fig. 2A). The tow body was connected by winch and electromechanical cable to a joystick. An operator controlled upwards and down-wards movement, following the topography of the seafloor, avoiding collisions with objects, and optimising the distance to target objects. Video imagery was directly transmitted, recorded on a shipboard miniDV tape recorder and received on a number of high definition digital monitors, where path and progress were observed with GPS (Fig. 2B). Categorical data describing the habitat and community characters were continuously entered by a second person using a computer based application running Visual Basic ${ }^{\mathrm{TM}}$ script (TowVid) developed by AIMS that also automatically recorded baseline data such as date, time, depth, longitude and latitude every two seconds [10]. Within the video transects the benthic communities were sampled with a custom-made epibenthic sled (Fig. 2C). Three replicate tows of $50 \mathrm{~m}$ length were sampled at each site. Sponge samples were photographed and preserved on the vessel (in ethanol or by freezing), and identified employing standard taxonomic methods at the Western Australian Museum [11]. The realtime characterisation data entered on board were used to create broad-scale maps for the macro-benthos. Further quantitative fine scale post-processing of the video transects is underway to determine percent cover of filter feeding communities. More comprehensive descriptions of the methods and results on non-biological data sets were provided by Colquhoun \& Heyward [12] and will be presented in forthcoming publications.

\section{PRELIMINARY REPORT ON THE SPONGE COMMUNITIES OF NINGALOO}

To date imagery data available for this project cover a bathymetric range of 18 to $102 \mathrm{~m}$ water depth and a distance of approximately $300 \mathrm{~km}$ from the Muiron Islands in the north to Red Bluff in the south (Fig. 3): ca. 350 transects of real time video and 150 transects for still photographs. Preliminary broad-scale, on-board analysis of video imagery clearly showed that sponges represent a significant proportion of the benthos in the deeper water of the Ningaloo

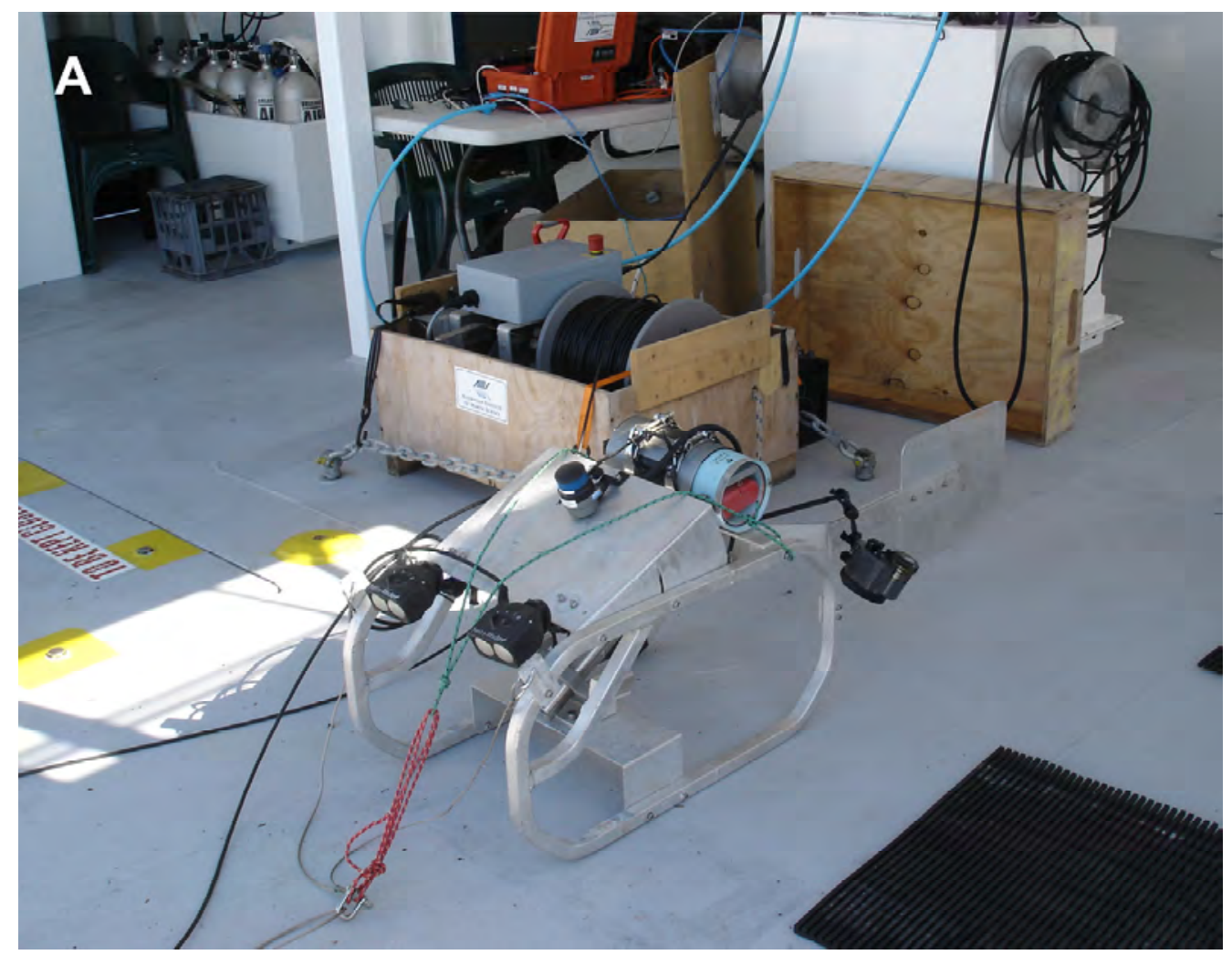

Towed Frame Equipped With Underwater Cameras And Light Strobes 
(Fig. 2) Contd.....

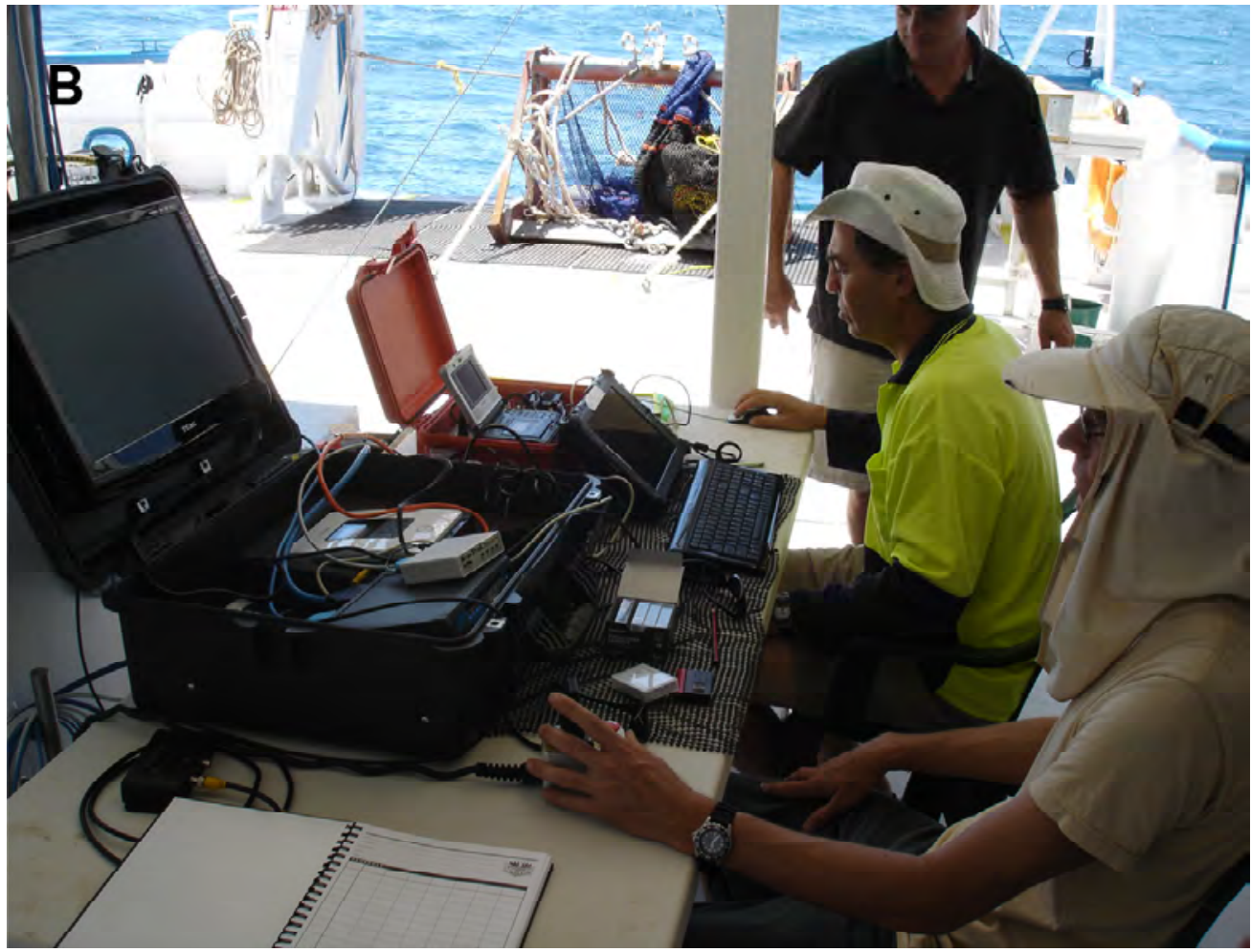

\section{Direct Images Transfer On Board}

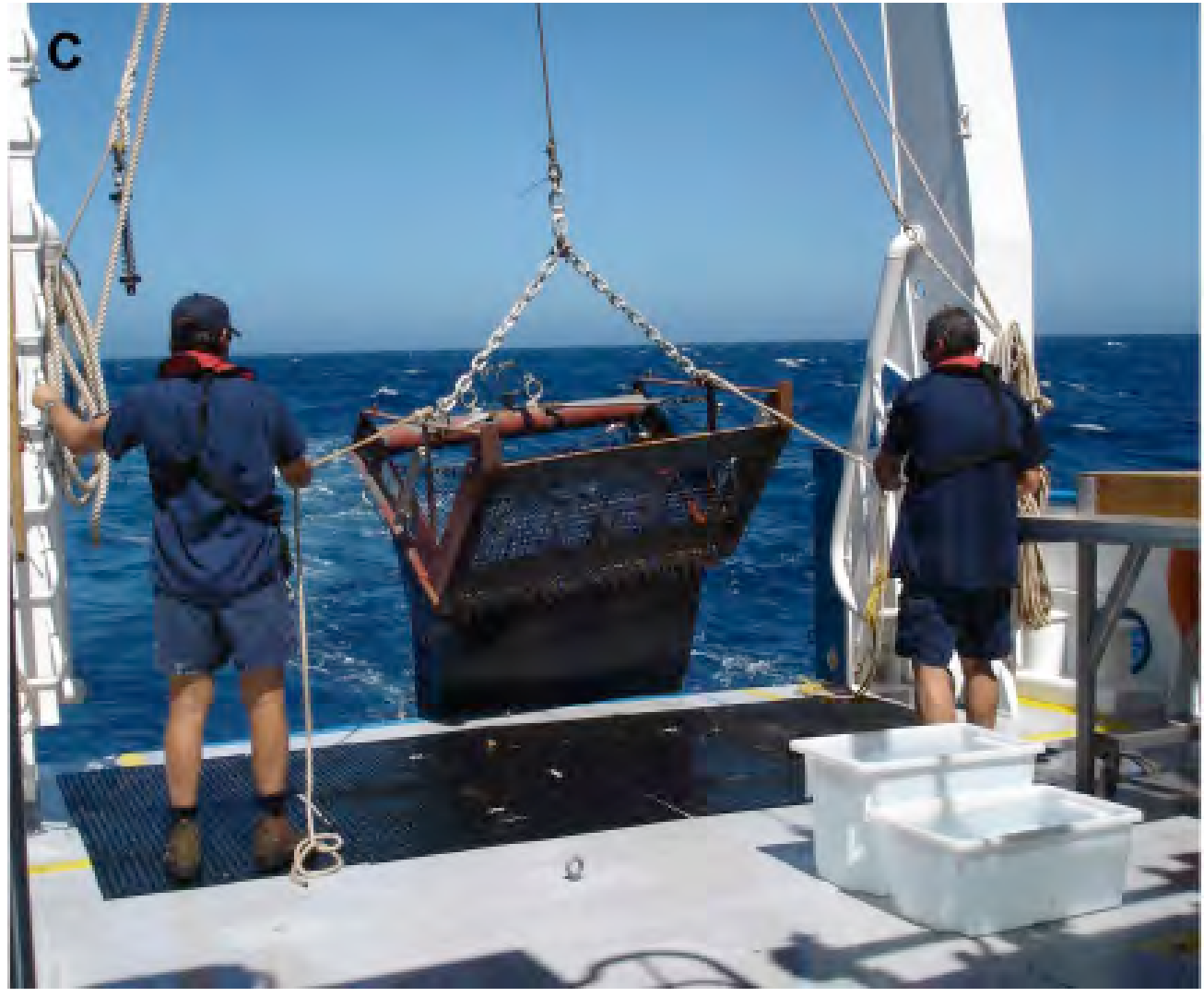

Epibenthic Sled Deployment

Fig. (2). The Ningaloo sponge gardens were surveyed in situ with video tows and still photography and then sampled with a sled. A - The towed frame equipped with underwater cameras and light strobes. B - Images were directly transferred on board to allow directed up and down movement related to topography and the logging of initial observations. $\mathbf{C}-$ The epibenthic sled is deployed from the back of the vessel. 


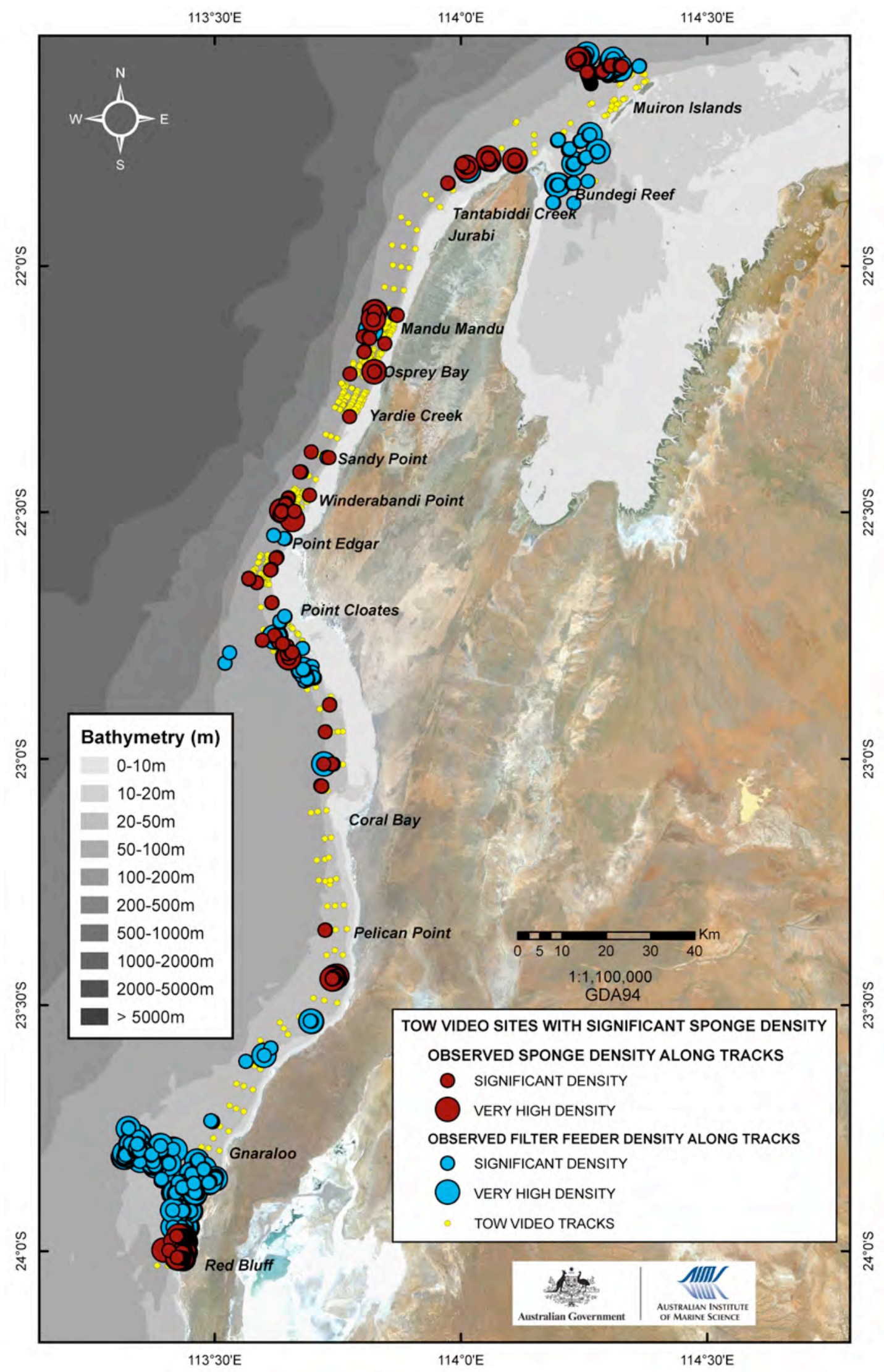

Fig. (3). Preliminary results for sponge densities for Ningaloo Reef as derived from video tows. Video observations were stopped every 5 seconds, and the resulting image was checked for any occurrence of sponges. Red dots signify data sets for which sponges have been analysed separately, blue dots were used for dense filter feeding communities that have not yet been resolved for sponges alone, but which were clearly dominated by sponges. 
Marine Park and are a major habitat-forming group. Various dense sponge communities or 'hotspots' have been identified including a few areas in the north at the Muiron Islands to Bundegi Reef and north of Tantabiddi, areas between Mandu Mandu and south of Point Cloates, and an area in the south between Gnaraloo and Red Bluff (Fig. 3). When viewing photographic material we recognized putative differences between the communities at different sampling sites and depths (Fig. 4). Consequently, the distribution of species needs to be examined to determine if representative species are included within the existing MPAs [9].

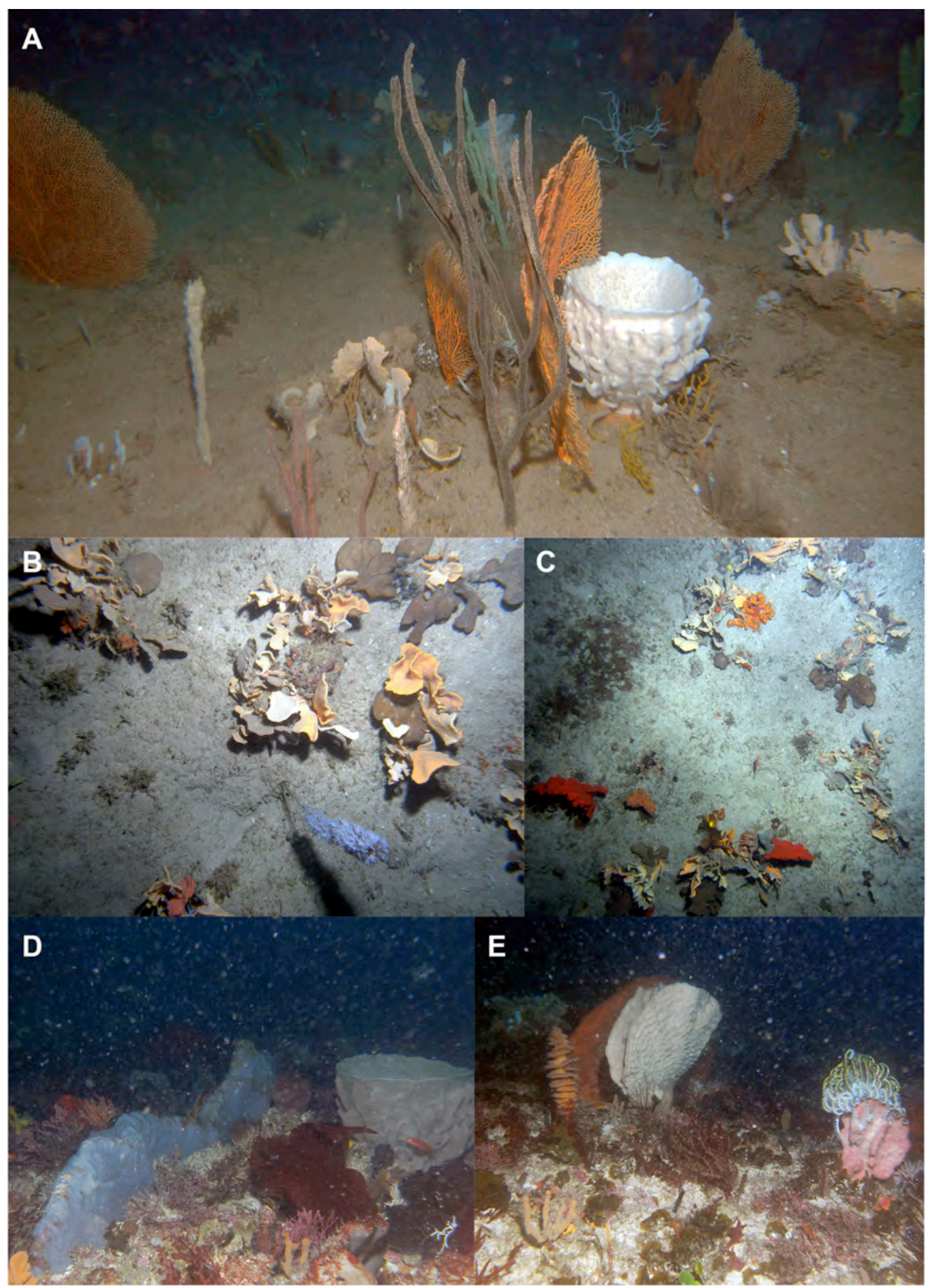

Fig. (4). Examples of Ningaloo Reef sponge communities taken from the tow body during various AIMS field trips. A - Typical filter feeding community off the Muiron Islands sites, forward view, B-C - Downward view at Jurabi. D-E - Very high sponge densities observed at Gnaraloo, forward view. 


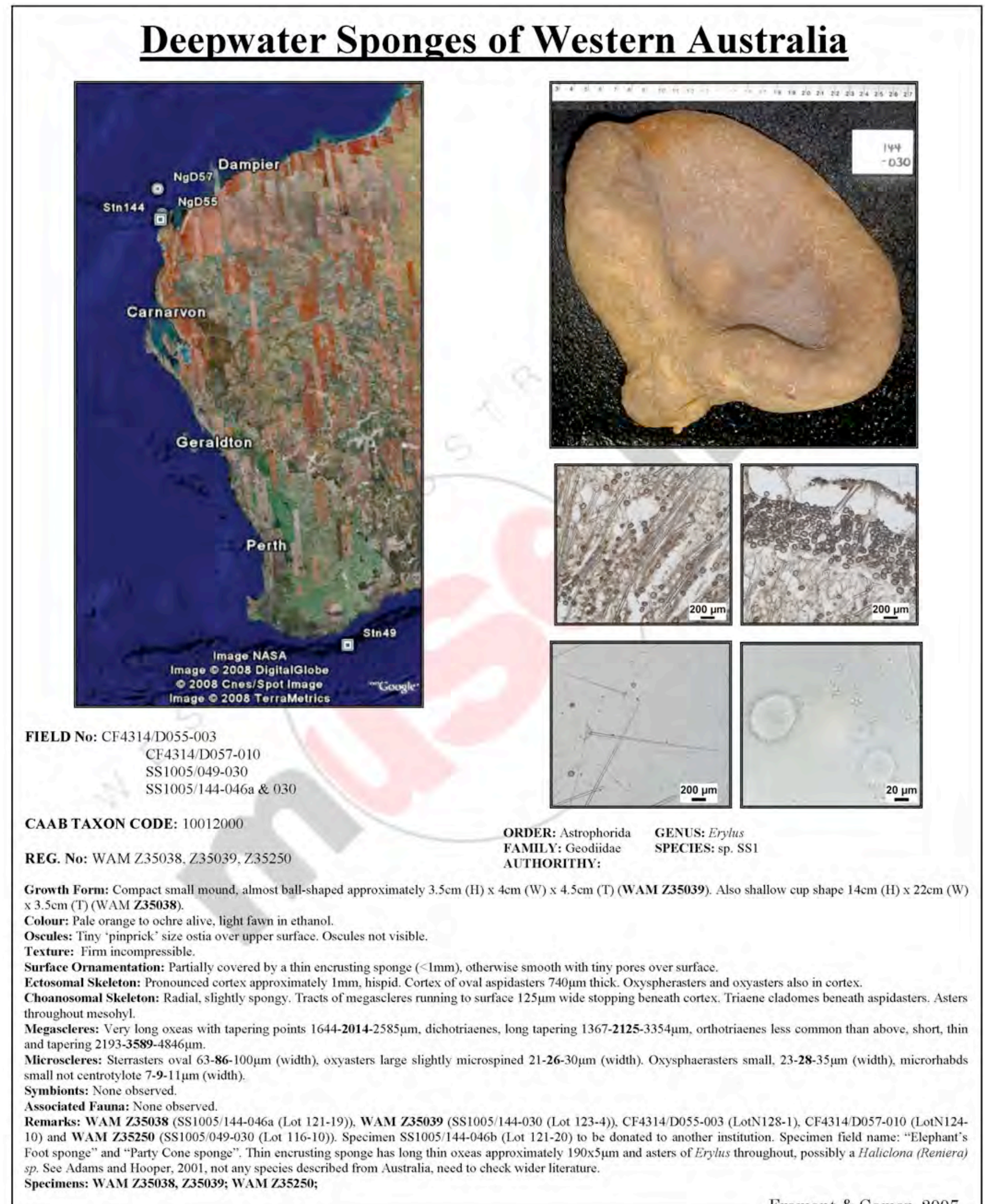

Fromont \& Gomez, 2007

Fig. (5). Example of a sponge identification sheet for an Erylus species occurring in Western Australia. As a result of taxonomic work at the Western Australian Museum 155 species identification sheets have been generated electronically for demosponges sampled from Ningaloo Reef. 
Sponge species identification sheets have been produced for each OTU (example see Fig. 5) following John Hooper's 'sponge mudmap system' (Queensland Museum). The species identification sheets document the main taxonomic characters of each dominant species and allow for cross referencing of specimens from other surveys, as a biodiversity management technique in lieu of our currently limited abilities to assign sponges to a new or known published taxon

The dominant sponges identified at the Western Australian Museum were all in the class Demospongiae and presently comprise 155 species (a dominant sponge species was one where the total weight of the species was $\geq 1 \mathrm{~kg}$ wet weight per station). Many more species were collected that did not attain wet weights $\geq 1 \mathrm{~kg}$ per station and are yet to be studied. The total number of sponge species present in the Ningaloo filter-feeding communities will be significantly higher when all species have been identified. Hooper et al. [13] also found very high diversities of sponges in three tropical regions of Australia: on mid- and outer-reefs of the Great Barrier Reef, Queensland (36 to 315 species per subsite), Darwin to the Wessel Islands in the Northern Territory (17 to 133 species per subsite), and the North West Shelf region of Western Australia (23 to 168 species per subsite). High diversities have also been reported from other Australian sponge surveys in the Great Australian Bight [109, 71 and 105 sponge species: 14, 15 and 16] and the Dampier Archipelago in the northwest of Western Australia [275 sponge species: 17]. With a present species count of 155 at Ningaloo, this study increases the regions where high sponge diversity has been reported in Australia and supports the notion that Australia's marine environments harbour important Porifera hotspots. Moreover, the Ningaloo sponge communities appear to be heterogeneous, containing species that appear to have locally restricted distributions (so-called short range endemics), even within the Marine Park. Hooper et al. [13] found between 32 and $44 \%$ of species were endemic in other areas in northwest Australia, values similar to our preliminary results for Ningaloo. While SCUBA divers and government agencies have been aware of these so-called 'unique sponge gardens' around southern parts of Australia for over 20 years, listing sites from Sydney Harbour to Tasmania and along the south and west coasts as far north as Exmouth Gulf, Western Australia [e.g. 18-20], the scientific world has yet to fully acknowledge the existence of these rich communities.

Furthermore, research has yet to determine what drives and sustains these sponge gardens. In the Dampier Archipelago, northwest Australia, the greatest diversity and abundance of sponges was found on limestone pavement in 'sponge garden' areas [17]. The Dampier region is characterized by large tides, strong currents and high turbidity, which are thought to be conducive to sponge growth and diversity [21]. In contrast, Ningaloo reef tract has clear, low productivity waters, with a low level of freshwater and sediment input [4]. Ecological studies on these sponge gardens are essential to determine the processes that maintain them through time, and data are needed on the trophic linkages between the sponge beds and adjacent coral reef.
ABBREVIATIONS
AIMS $=$ Australian Institute of Marine Science
GPS = Global Positioning System
MPA $=$ Marine Protected Area
$\mathrm{RV}=$ Research Vessel

\section{ACKNOWLEDGEMENTS}

The authors acknowledge the assistance provided by the crews of the $R V$ Cape Ferguson and $R V$ Solander and Mark Salotti, Western Australian Museum for sorting and preserving the sponges. The project was conducted with support and funding from the Western Australian Marine Science Institute (WAMSI) and the Australian Government's Commonwealth Environment Research Facilities (CERF) Programme. This study is part of WAMSI Node 3 Project 3.1.1: Deepwater Communities at Ningaloo Marine Park.

\section{REFERENCES}

[1] Taylor JF, Pearce AF. Ningaloo reef currents: implications for coral spawn dispersal, zooplankton and whale shark abundance. J Royal Soc West Aust 1999; 82: 57-65

[2] MPRA CALM CCPAC. Management Plan for the Ningaloo Marine Park and Muiron Islands Marine Management Area 20052015. Management Plan Number 522005.

[3] Roberts CM, McClean CJ, Veron JEN et al. Marine biodiversity hotspots and conservation priorities for tropical reefs. Science 2002; 295: 1280-4.

[4] CALM. Ningaloo Marine Park Draft Management Plan. Department of Conservation and Land Management, Perth, Western Australia 2004.

[5] Australian Geographic [homepage on the Internet]. Sydney, Australia: Australian Geographic [updated daily; cited 2009 July 14]. Available from: http://www.australiangeographic.com.au/ journal/ningaloo-revealed.htm

[6] Ningaloo Marine Park (Commonwealth Waters) Management Plan. Natural Heritage Trust \& Environment Australia 2002.

[7] Chin A, Sweatman H, Forbes S, et al. Status of the coral reefs in Australia and Papua New Guinea. In: Wilkinson C, Ed. Status of coral reefs of the world: 2008. Global Coral Reef Monitoring Network and Rainforest Research Centre, Townsville, Australia 2008; pp. 159-176.

[8] Stevens T, Connolly RM. Testing the utility of abiotic surrogates for marine habitat mapping at scales relevant to management. Biol Conserv 2004; 119: 351-62.

[9] Jordan A, Lawler M, Halley V, Barrett N. Seabed habitat mapping in the Kent Group of islands and its role in marine protected area planning. Aquatic Conserv: Mar Freshw Ecosyst 2005; 15: 51-70.

[10] Speare P, Cappo M, Rees M, Brownlie J, Oxley W. Deeper water fish and benthic surveys in the Lord Howe Island Marine Park (Commonwealth Waters): February 2004. Australian Inst Mar Sci Publ, Townsville, Australia 2004.

[11] Fromont J. Porifera (sponges) of the Dampier Archipelago, Western Australia: habitats and distribution. In: Jones DS, Ed Aquatic fauna of the waters of the Dampier Archipelago, Western Australia. Report of the Woodside Energy Ltd/Western Australia Museum Partnership to Explore the Marine Biodiversity of the Dampier Archipelago, 1998-2001. Rec West Aust Mus Suppl 2004; 66: 69-100.

[12] Colquhoun J, Heyward A, Eds. Ningaloo Reef Marine Park deepwater benthic biodiversity survey. Annl Report 2007. Joint report by the Australian Institute of Marine Science, Curtin University of Technology, The University of Western Australia and the Western Australian Museum. Perth 2008.

[13] Hooper JNA, Kennedy JA, Quinn RJ. Biodiversity 'hotspots', patterns of richness and endemism, and taxonomic affinities of tropical Australian sponges (Porifera). Biodivers Conserv 2002; 11: $851-85$. 
[14] Sorokin S, Fromont, J, Currie D. Demosponge biodiversity in the Great Australian Bight's benthic protection zone. Trans Royal Soc South Aust 2007; 131: 192-204.

[15] Sorokin SJ, Laperousaz TCD, Collings GJ. Investigator Group Expedition 2006: sponges (Porifera). Trans Royal Soc South Aust 2008; 132: 163-72.

[16] Sorokin SJ, Currie DR. The distribution and diversity of sponges in Spencer Gulf. Report to Nature Foundation SA Inc. SARDI Aquatic Sciences Publication F2008/001153-1, SARDI Res Report Ser 2009; 334

[17] Fromont J, Vanderklift MA, Kendrick GA. Marine sponges of the Dampier Archipelago, Western Australia: patterns of species distributions, abundance and diversity. Biodivers Conserv 2006; 15: $3731-50$

[18] Coleman N. Australian sea life: south of $30^{\circ}$ S. Sydney: Doubleday 1987.

[19] Coleman N, Marsh N. Diving Australia. A guide to the best diving down under. Sydney: Tuttle Publishing 2003.

[20] The Marine and Coastal Community Network. Australia's Unique South - sponge gardens. Yeronga, Australia 1998.

[21] Voogd NJ de, Soest RWM van, Hoeksema BW. Cross-shelf distribution of Southwest Sulawesi reef sponges. Mem Queensland Mus 1999; 44: 147-54.

Received: May 31, 2009

(C) Heyward et al.; Licensee Bentham Open.

This is an open access article licensed under the terms of the Creative Commons Attribution Non-Commercial License (http://creativecommons.org/licenses/by$\mathrm{nc} / 3.0 /$ ), which permits unrestricted, non-commercial use, distribution and reproduction in any medium, provided the work is properly cited. 